\title{
Nargiz Gurbanova
}

Ambasador Nadzwyczajny i Pełnomocny

Republiki Azerbejdżanu w Rzeczypospolitej Polskiej

\section{The 44-day Patriotic War: background and a way forward}

he conflict between Armenia and Azerbaijan started at the end of 1987, when both
republics were part of the former Union of Soviet Socialist Republics (USSR), with Armenia's territorial claims on the Nagorno-Karabakh region (Nagorno-Karabakh Autonomous Oblast, NKAO) of Azerbaijan. Although, the Armenian side tried to disguise these claims as those driven by concerns over Armenians residing in the region, they in fact were part of a long cherished policy to annex and ethnically cleanse the territories of Azerbaijan. Between 1987 and 1988, over 250000 of Azerbaijanis were assaulted and expelled both from the Nagorno-Karabakh region of Azerbaijan and from the territories of the Republic of Armenia where their ancestors had lived for centuries. Moreover, contrary to the USSR Constitution ${ }^{28}$, both Armenia and the extremist elements among the Armenian community of the Nagorno-Karabakh region adopted a number of decisions to institute the process of unilateral secession of the autonomous oblast from Azerbaijan, including the resolution of the Supreme Soviet of the Armenian Soviet Socialist Republic on the unification of the Armenian Soviet Socialist Republic and NKAO of 1 December 1989. Both Armenia and Azerbaijan came to independence and were recognized as such in accordance with international law within the boundaries that they had had as Republics of the USSR. Accordingly, the definition of the territory of Azerbaijan as it proceeded to independence and in the light of the applicable law clearly included the territory of the former $\mathrm{NKAO}^{29}$.

\footnotetext{
${ }^{28}$ According to article 78 of the Constitution of the USSR, the territory of a Union Republic could not be altered without its consent, while the borders between the Union Republics could be altered by the mutual agreement of the Republics concerned, subject to approval by the USSR.

${ }^{29}$ For more information, see letters dated 20 September 2019 from the Permanent Representative of Azerbaijan to the United Nations addressed to the Secretary-General, the President of the General Assembly and the President of the Security Council, A/74/450-S/2019/762 (23 September 2019)and Malcolm N. Shaw, "Report on the fundamental norm of the territorial integrity of States and the right to self-determination in the light of Armenia's revisionist claims", A/74/961-S/2020/729, 22 July 2020, annex, p. 154-178.
} 
Fighting in the Nagorno-Karabakh region intensified after independence of Armenia and Azerbaijan, followed by the increased involvement of troops from the Republic of Armenia during this period. The first armed attack by the Republic of Armenia against the Republic of Azerbaijan - an attack in which organized military formations and armoured vehicles operated against Azerbaijani targets - occurred in February 1992, when the town of Khojaly in the Republic of Azerbaijan was notoriously overrun and its population was subjected to an unprecedented genocide. This bloody tragedy, which became known as the Khojaly genocide, involved the extermination or capture of thousands of Azerbaijanis; the town was razed to the ground. Invaders destroyed Khojaly and with particular brutality implemented carnage over its peaceful population. As a result, 613 civilians were killed, including 106 women, 63 children and 70 elderly. Another 1,000 people were wounded and 1,275 taken hostage. To this day, 150 people from Khojaly remain missing ${ }^{30}$.

The war claimed the lives of tens of thousands of people and ruined cities, towns and villages; all captured areas were ethnically cleansed of more than 750,000 Azerbaijanis. Likewise, about 250,000 Azerbaijanis, out of a population of once half a million who had remained in Armenia, were also brutally expelled from their ancestral lands at the end of 1980s. As a result, a significant part of the territory of Azerbaijan, including the NagornoKarabakh region, the seven surrounding districts (Lachyn, Kalbajar, Zangilan, Gubadly, Jabrayil, parts of Fuzuli and Aghdam) and some exclaves, was occupied by Armenia. Some of the offences committed by the Armenian side during the conflict, which constitute war crimes, also amount to the crime of genocide, as ethnic Azerbaijanis have been targeted because of their nationality and/or ethnicity, and the relevant intent has been to destroy the group in part $^{31}$.

In its resolutions 822 (1993), 853 (1993), 874 (1993) and 884 (1993), the Security Council condemned the use of force against Azerbaijan and the occupation of its territories and reaffirmed respect for the sovereignty and territorial integrity of Azerbaijan, the inviolability of international borders and the inadmissibility of the use of force for the acquisition of territory. The Security Council reconfirmed that the Nagorno-Karabakh region and other occupied districts are an integral part of Azerbaijan and demanded the immediate, complete and unconditional withdrawal of the occupying forces from all the occupied

\footnotetext{
${ }^{30}$ Statement of the Commissioner for Human Rights (Ombudsman) of the Republic of Azerbaijan on the 29th anniversary of Khojaly Genocide, 22February 2021, p. 1.

${ }^{31}$ Malcolm N. Shaw, Naomi Hart, Report on war crimes in the occupied territories of the Republic of Azerbaijan and the Republic of Armenia's responsibility, United Nations document A/74/676-S/2020/90 (7 February 2020).
} 
territories. The General Assembly, in particular in its resolution 62/243, entitled "The situation in the occupied territories of Azerbaijan",32, and other international organizations have adopted a similar position.

In its judgment of 16 June 2015 in the case of Chiragov and Others v. Armenia, the Grand Chamber of the European Court of Human Rights established that Armenia exercised effective control over the Nagorno-Karabakh region and other occupied territories of Azerbaijan and thus was responsible for violations of international law in those territories. The conclusion reached was that:

- The Republic of Armenia, "through its military presence and the provision of military equipment and expertise, has been significantly involved in the Nagorno-Karabakh conflict from an early date".

- "This military support has been - and continues to be - decisive for the conquest of and continued control over the territories in issue".

- The regime in those territories survives "by virtue of the military, political, financial and other support given to it by Armenia which, consequently, exercises effective control over Nagorno-Karabakh and the surrounding territories"33.

Regretfully, the mediation efforts by the OSCE Minsk Group and its co-chairmen over the last three decades yielded no substantive results. Yet, Azerbaijan has a solid track-record of pushing for result-oriented substantive negotiations to achieve progress in political resolution of the conflict. To this end, Azerbaijan called for active involvement of the OSCE Minsk Group and none of the members of this group, except Turkey, reciprocated these calls. It should be noted that the primary objective of the peace process pursued within the OSCE Minsk Group had been elimination of the major consequences of the conflict, thus ensuring immediate, complete and unconditional withdrawal of the Armenia's armed forces from the occupied territories of Azerbaijan and restoring the sovereignty and territorial integrity of Azerbaijan.

That was what international law, the UN Security Council resolutions and OSCE documents and decisions unequivocally demanded. However, Azerbaijan's plea to resolve the conflict peacefully through negotiations fell on deaf ears. The never ending process of informal meetings that did not bring any tangible results over the past years only played

\footnotetext{
32 For more information, see 62/243. The situation in the occupied territories of Azerbaijan, https://undocs.org/en/A/RES/62/243

${ }^{33}$ Chiragov and Others v. Armenia, App. No. 13216/05, ECHR (Grand Chamber), 16 June 2015, p.180 and 186.
} 
into the hands of Armenia, which pursued the obvious goal of undermining the efforts towards the political resolution of the conflict and consolidating the status-quo of occupation.

We witnessed consistent attempts by the leadership of Armenia to derail the peace process by resorting to irresponsible statements and actions, which indicate that this country chose not to seize the opportunity to engage constructively in the negotiations. Armenia continued to challenge the format of negotiations agreed upon by the OSCE participating States by consensus and endorsed by the UN Security Council. As a means of implementing its annexation policy, Armenia has encouraged and facilitated the transfer of thousands of settlers into the occupied territories from Armenia and abroad and has extensively exploited natural resources and other wealth in those territories, in clear violation of international law and in contravention of the objectives of the political settlement of the conflict.

Instead of delivering to its commitment to prepare its population for peace, the current Armenian leadership replicated its predecessors' annexationist policy, both in words and deeds. Armenian senior officials publicly denounced their adherence to the logic and understandings underlying the OSCE Minsk Group-led negotiation process for years, in an overt attempt to derail the peace process. In parallel, Armenia spared no effort to prolong the illegal occupation on the ground. In March and April 2020, Armenia staged in the occupied territories of Azerbaijan so-called "elections" in an attempt to give the puppet regime it has set up in those territories the appearance of some kind of legitimacy.

The international community once again overwhelmingly reaffirmed its consistent and principled position of collective non-recognition of the situation resulting from the occupation of the territories of Azerbaijan by rejecting and invalidating the so-called "elections", which thus have no effect whatsoever ${ }^{34}$. It should be noted that these so-called "elections" were staged despite the unprecedented spread of the COVID-19 pandemic across the globe, in total disregard of public morality and in violation of international humanitarian law, which aggravated public health threats.

At the same time, Armenia attempted to exploit the COVID-19 pandemic for its political purposes, including for the propagation of the illegal puppet regime, in defiance of universal values, norms, principles and standards. Announcement on the construction of third highway linking Armenia to the occupied territories of Azerbaijan was yet another

${ }^{34}$ NAM CoB adopted Communique on so-called "elections" in the occupied territories of Azerbaijan, https://www.namazerbaijan.org/news/34 
attempt by Armenia to consolidate the occupation of territories with potential risk of escalation.

Extremely provocative statements and actions of Armenia, which pursued the obvious goal of consolidating the status-quo did not receive adequate reaction and condemnation, which, to a large extent, contributed to the all-out war with all its consequences. Over this period, Armenia has repeatedly carried out armed provocations on the ground, which have caused numerous casualties among the Azerbaijani civilians and militaries.

On 27 September 2020, Armenia perpetrated yet another act of aggression, subjecting the positions of the armed forces of Azerbaijan along the front line and the adjacent populated areas of Azerbaijan to intensive fire with the use of large-calibre weapons, artillery and mortars. The combat actions that followed have lasted for 44 day.

The report of Human Rights Watch provides the findings of its investigation of missile, rocket and artillery attacks by Armenian forces that struck Aghdam, Barda, Fuzuli, Ganja, Goranboy, Naftalan and Tartar in Azerbaijan. Investigations conducted by international non-governmental organizations (Amnesty International, Human Rights Watch also confirmed the repeated use by Armenia of the prohibited weapons. Ganja, the second largest city of Azerbaijan, was hit three times. Two strikes, on 11 and 17 October, with the use of Scud ballistic missiles were launched from the territory of Armenia, claiming the lives of 25 civilians and injuring more than 84 civilians. On 28 October, the city centre of Barda came under the massive fire with Smerch multiple-launch rocket systems, causing the death of 21 civilians and injuring more than 70 civilians. In total, as a result of direct and indiscriminate attacks carried out by the armed forces of Armenia between 27 September and 9 November 2020, 101 Azerbaijani civilians, including 12 children, were killed, 423 civilians were wounded, almost 84,000 people were forced to leave their homes and over 4,300 private houses and apartment buildings and 548 other civilian objects were either destroyed or damaged.

In order to repulse the aggression, Azerbaijan had taken counteroffensive measures in the exercise of its inherent right of self-defence. Azerbaijan acted exclusively on its sovereign soil to protect its civilian population, liberate the occupied territories from aggressors and terrorists and allow over 750,000 internally displaced persons to return to their homes and properties in dignity and safety. As a result of 'Iron Fist' counter-offensive operation launched by the Armed Forces of Azerbaijan, which lasted for 44 days, Azerbaijan liberated significant part of its occupied territories (some $10,000 \mathrm{~km}^{2}$ of the territory 
of Azerbaijan - more than 300 cities, towns and villages) and on 8 November by liberating the city of Shusha forced the Armenia's armed forces to capitulate.

The statement of the President of the Republic of Azerbaijan, the Prime Minister of the Republic of Armenia and the President of the Russian Federation, signed on 10 November 2020, has put an end to the almost three-decades-old armed conflict between Armenia and Azerbaijan and set agreed parameters for establishing durable peace in the region ${ }^{35}$. Implementation of this agreement ensured cessation of all military activities and return of Aghdam, Kalbajar and Lachyn districts to Azerbaijan. The statement also contains an important provision related to the return of the internally displaced persons (IDPs) and refugees to their homes under the supervision of the UNHCR. On 11 January 2021, the leaders of the Republic of Azerbaijan, the Republic of Armenia and the Russian Federation signed another joint statement aimed at implementing a number of practical steps to remove obstacles to economic and transport links in the region ${ }^{36}$.

The new situation has paved the way for hundreds of thousands of IDPs to exercise their right to a safe and dignified return to their places of origin and, despite the devastating consequences of the war, offers a unique opportunity and real prospects for building peace, consolidating stability, restoring peaceful coexistence, advancing the reconciliation agenda and investing in economic development and cooperation. For these reasons, sustaining peace, rehabilitation and reconstruction activities, providing humanitarian assistance to those in need, including returning IDPs and refugees, should be absolute priority. To this end, Azerbaijan is ready to work with relevant international partners, including ICRC, UNHCR and other UN agencies as well as with partner states like Poland which are willing to contribute to peace and stability in the region, in full compliance with the United Nations Guiding Principles on humanitarian assistance of $1991^{37}$.

The new realities established by Azerbaijan are offering a unique opportunity to consolidate peace in the region and set it on the course of mutually beneficial comprehensive multilateral cooperation that can eradicate the risks of new wars in the region. Yet, Azerbaijan is faced with major mine contamination of its recently liberated territories,

\footnotetext{
${ }^{35}$ Statement by the President of the Republic of Azerbaijan, the Prime Minister of the Republic of Armenia and the President of the Russian Federation, 9 November 2020, https:/www.mid.ru/en/foreign_policy/news//asset_publisher/cKNonkJE02Bw/content/id/4419267.

36 Statement by President of the Republic of Azerbaijan, Prime Minister of the Republic of Armenia and President of the Russian Federation, 11 january 2021, https://en.president.az/articles/50070.

${ }^{37}$ Statement by H.E. Mr. Jeyhun Bayramov, Minister of Foreign Affairs of the Republic of Azerbaijan at the 27th Meeting of the OSCE Ministerial Council, 3-4 December 2020, https://mfa.gov.az/en/news/7065/view
} 
which represents a serious threat to the life, safety, and livelihoods of both military and civilians in the post-conflict period. The Government of Armenia refuses to share the location of these mines in order to make the region safe ${ }^{38}$. At the same time, members of the armed forces of Armenia, wearing civilian dress, had been transferred to the territory of Azerbaijan through the "Lachin Corridor" in civilian trucks, including disguised among construction cargo, in an attempt to escape the control procedures of the Russian peacekeeping contingent ${ }^{39}$.

By continuing to illegally deploy its armed personnel to the territory of Azerbaijan, refusing to release information regarding the minefields in the liberated areas, circulating various papers in the name of the remnants of the illegal puppet regime and the non-existent entity, referencing the localities of the Republic of Azerbaijan with fabricated names and denying its responsibility for numerous war crimes committed during the conflict, Armenia clearly demonstrates its unwillingness to comply with its international obligations and refrain from confrontational policy.

Azerbaijan considers any kind of revanchist propaganda and revisionist claims by Armenia as an attempt to undermine the trilateral agreement of 10 November 2020, an infringement upon the sovereignty and territorial integrity of Azerbaijan and a threat to the rights and legitimate interests of its people, with all the ensuing consequences under international law, for which Armenia will bear full responsibility.

We are entering a new post-conflict stage, a stage of reconstruction and rehabilitation, a stage of restoration of peaceful co-existence. Facing serious socioeconomic challenges and high levels of migration of its citizens from the country, Armenia would definitely benefit from the normalization of inter-State relations with Azerbaijan based on mutual recognition and respect for each other's sovereignty and territorial integrity within their internationally recognized borders.

Azerbaijan is resolute to re-integrate its citizens of Armenian origin residing in the territories of the Nagorno-Karabakh region of the Republic of Azerbaijan into its political, social, economic space, guaranteeing the same rights and freedoms with all the citizens of Azerbaijan regardless of their ethnic, religious affiliation on an equal and non-

\footnotetext{
${ }^{38}$ Letter dated 23 February 2021 from the Permanent Representative of Azerbaijan to the United Nations addressed to the Secretary-General, A/75/778-S/2021/177, 24 February 2021, annex, p. 2.

${ }^{39}$ Letter dated 2 March 2021 from the Permanent Representative of Azerbaijan to the United Nations addressed to the Secretary-General, A/75/791-S/2021/212, 3 March 2021, annex, p. 1.
} 
discriminatory basis. The Constitution of the Republic of Azerbaijan provides the solid legal framework in this regard.

\section{Streszczenie:}

Konflikt między Armenią a Azerbejdżanem rozpoczął się pod koniec 1987 roku, kiedy obie republiki były częścią byłego Związku Socjalistycznych Republik Radzieckich (ZSRR), a Armenia wysuwała roszczenia terytorialne do regionu Górskiego Karabachu (Autonomiczny Okręg Górskiego Karabachu (AOGK)). Na początku lat $90 \mathrm{XX}$ wieku Armenia i Azerbejdżan uzyskały niepodległość i zostały uznane za takie zgodnie z prawem międzynarodowym $\mathrm{w}$ granicach, które posiadały, jako republiki ZSRR. W związku z tym definicja terytorium Azerbejdżanu w procesie uzyskiwania niepodległości i w świetle obowiązujących przepisów, jednoznacznie obejmuje terytorium byłego AOGK. 44-dniowa wojna 2020 roku zakończyła się podpisaniem 10 listopada tego samego roku, porozumienia trójstronnego i wyzwoleniem terytoriów azerbejdżańskich spod okupacji. Dziś Azerbejdżan uważa wszelkie odwetowe, propagandowe i rewizjonistyczne roszczenia Armenii za próbę podważenia tego porozumienia i naruszenie suwerenności i integralności terytorialnej Azerbejdżanu oraz zagrożenie dla praw i uzasadnionych interesów jego narodu, zgodnie z prawem międzynarodowym, za które Armenia będzie w pełni odpowiedzialna.

\section{Slowa kluczowe:}

Karabach, Rada Bezpieczeństwa, Chodżały, Azerbejdżan, Szusza

\section{Key words:}

Karabakh, Security Council, Khojaly, Azerbaijan, Shuha

\section{Bibliografia:}

1. Chiragov and Others v. Armenia, App. No. 13216/05, ECHR (Grand Chamber), 16 June 2015, p.180 and 186.

2. Letters dated 20 September 2019 from the Permanent Representative of Azerbaijan to the United Nations addressed to the Secretary-General, the President of the General Assembly and the President of the Security Council, A/74/450-S/2019/762 (23 September 2019)

3. Letter dated 23 February 2021 from the Permanent Representative of Azerbaijan to the United Nations addressed to the Secretary-General, A/75/778-S/2021/177, 24

February 2021, annex, p. 2.

4. Letter dated 2 March 2021 from the Permanent Representative of Azerbaijan to the United Nations addressed to the Secretary-General, A/75/791-S/2021/212, 3 March 2021, annex, p. 1.

5. Malcolm N. Shaw, "Report on the fundamental norm of the territorial integrity of States and the right to self-determination in the light of Armenia's revisionist claims", A/74/961-S/2020/729, 22 July 2020, annex, p. 154-178. 
6. Malcolm N. Shaw, Naomi Hart, Report on war crimes in the occupied territories of the Republic of Azerbaijan and the Republic of Armenia's responsibility, United Nations document A/74/676-S/2020/90 (7 February 2020).

7. NAM CoB adopted Communique on so-called "elections" in the occupied territories of Azerbaijan, https://www.namazerbaijan.org/news/34

8. Statement of the Commissioner for Human Rights (Ombudsman) of the Republic of Azerbaijan on the 29th anniversary of Khojaly Genocide, 22February 2021, p. 1.

9. Statement by the President of the Republic of Azerbaijan, the Prime Minister of the Republic of Armenia and the President of the Russian Federation, 9 November 2020, https://www.mid.ru/en/foreign_policy/news/-

/asset_publisher/cKNonkJE02Bw/content/id/4419267.

10. Statement by President of the Republic of Azerbaijan, Prime Minister of the Republic of Armenia and President of the Russian Federation, 11 january 2021, https://en.president.az/articles/50070.

11. Statement by H.E. Mr. Jeyhun Bayramov, Minister of Foreign Affairs of the Republic of Azerbaijan at the 27th Meeting of the OSCE Ministerial Council, 3-4 December 2020, https://mfa.gov.az/en/news/7065/view

12. The situation in the occupied territories of Azerbaijan, https://undocs.org/en/A/RES/62/243 